\title{
Determination of the Impacts of the Existence of Public/Private Clinics (Mix) in the Delivery of Healthcare and Safety Services to the Employees in Nigeria and Malaysia under Healthcare and Safety Reform
}

\author{
Yahya Saleh Ibrahim (Corresponding author) \\ University Utara Malaysia, College of Arts and Social Sciences, Occupational Safety and Health Management \\ Dpp Maybank, Student Residential Hall, Block W Room 204, UUM, 06010 Sintok Kedah, Darul, Aman \\ E-mail: Ysibrahim2005@yahoo.com
}

Mohamad Khan Jamal Khan

Cyberjaya University College of Medical Sciences (CUCMS)

Jalan Teknokrat 3, Cyber 4, 6300 Cyberjaya, Selengor Darul Ehsan, Malaysia

E-mail: Mohamad.khan@cybermed.edu.my

Received: April 29, 2011 Accepted: May 12, 2011 doi:10.5539/gjhs.v3n2p175

\begin{abstract}
Based on the assumption of most health expert, paramedics, health economist, reformists and labor/safety proponents is that, the healthcare and safety services can only be available to common man when the process is partially or fully mixed (public-private). That is to them, the private sector participation in healthcare and safety sect oral service provision is eminent. In the payment for healthcare and safety services it was concluded that, the relative efficiency of payments through private insurance scheme or its impacts on the efficiency of public sector is not debatable. It is also postulated that the private/public mix may evolve the possibility of reduction in administrative bottle necks, improve access at an affordable price, and ensure equity through the use of government control mechanisms. The target respondents were medical doctors, nurses, paramedics, human resource personnel and healthcare and safety beneficiaries in Nigeria and Malaysian higher institution as well as both public and private clinics. A random sampling technique was used. A log-linear and chi-square test was used for the analysis of the750 sample respondents in both Nigeria and Malaysia. The study revealed the following results/relationship between Nigeria and Malaysian National Healthcare Scheme and Safety under reform which show $r=0.257$ with $p=0.000$ which is less than 0.05 , therefore significant, relationship between public control health and healthcare service delivery for safety under reform revealed $r=0.164$ and $p=0.008$ and 0.005 which is significant, so also as reform ensures efficiency in healthcare delivery services to employees it in turn ensures equity and safety of employees with $r=201, p=0.006$ and 0.005 therefore significant and finally control mechanism instituted by the government ensures access and equity improvement in healthcare and safety services to employees under reform.
\end{abstract}

Keywords: Impacts, Private/public clinic mix, Employees, Health/Safety Services, Reform

\section{Introduction}

Safety and health awareness has long history, some evidences went as far back as the period of pharoahs, the Hammurabi code of safety and health exists in circa 2000 BC., the Roman, safety and health attempt, the USA, 1892 records of safety and health, USA Mines and Bureau of 1907, Workers Compensation law 1911 and OSHA law of 1970. The identification of diseases such as lung diseases among Miners, mercury poisoning and lung cancer associated with asbestors particulates, contributed immensely in the development of safety and health regulation in the work place (Goetsh, 2005). The issue of workers health fitness, later necessitated the involvement of labor in the organization and reform in health sector to take care of workers in the work place (OSHA, 2005). The Nigerian healthcare reform was initiated not only to meet with the health demand of the employees but for the employees to subsidize for the general public (crosssusidization) sytem. The policies 
receive contribution from both public and private formal sector empolyees in the country (NHIS Decree, 1999; HERFON, 2006). The Malaysian reform started with the coming of the private clinics prominently in the provision of healthcare and safety service to the interested citizens in the 1980's. The effort was back up with the coming up of insurance Act of 1996 and private healthcare and safety facilities and services Act of 1998, this is in addition to the 2006 coming on board the National Healthcare Finance Scheme and Health Provident Fund which gave impetus to the coming up of CUEPECS and related insurance outfits in Malaysia (Nik and Daniel, 2009; Jacob, 2008; Datuk Chua Soi Lek, 2004). Therefore this study focuses on the assesment of the reform in healthcare and safety service provision in Nigeria and Malaysia.

\subsection{Literature review}

Drechler and Juttling, (2005) argue that there are positive sides to private health insurance, their small sizes can reduce bureaucratic processes and hence can work more efficiently than social insurance scheme. There are also some prevailing views that private financing system are less able to hold down costs (MCAuley, 1993; Propper \& Green, 1999; Ramesh \& Wu, 2008).The argument is that although an expanding role of the private health insurance may reduce government spending on health, the aggregate health costs could increase. This is because with higher levels of private health insurance there would be higher administrative charges or costs, fewer controls on over servicing, and the reluctance of private funds to encourage costs containment methods in private hospitals. As suggested by Bloom, Craig, and Mitchell, (2000) the private sector is neither so easy to characterize nor easy to neglect. Its strength is its innovativeness, efficiency and learning from competition. This factor plus the fact that in many developing countries, the private sector accounts for a large proportion of services and resources in the health sector, it is argued that strategies to improve the health system and payments should take into account of the strengths of the private sector (World Bank, 2004).

National health care for all is the new slogan all over the world today, both developed and developing countries alike. To achieve healthcare for all in our ever populated world is not going to be a simple task, therefore, the ultimate is the involvement of private sector in the provision of healthcare services and facilities. This led to the evolution of public-private partnership in the name of meeting the societal demand for medical and health care services.

The NHS is one of those arrangement as fortified by WHO (2001) that given the respective strengths and weakness of the public sector and private sector, neither party can operate alone in the interest of the public, in payment for health services a meeting point should be created for both of them.

Added to the above, is the belief that, public and private health sector in the provision of health care services can potentially gain from one another (Bloom et al., 2000; Agha et al., 2003).

The Government of both Nigeria and Malaysia complained of increase in governmental spending on healthcare provision in their respective countries. Currently only 1 million people in Nigeria, or 0.8 percent of the population are covered by health insurance schemes. Many poor people have to pay out-of-pocket for medical care or do without. The National Health Insurance Scheme introduced in 2005, is ultimately intended to cover all Nigerians, but many low- income population are not expected to benefit for at least another ten years (World Bank, 2009).This is the more reason why this research is timely and important, in trying to contribute towards having literature on the available statistics on health and related phenomena (Collins \& Alison, 1992).

According to the, Malaysian Health Minister, Datuk Dr Chua Soi Lek, in his response to the healthcare condition in Malaysia, that, due to the rising healthcare expenditure, the Malaysian government has recently announced that it will implement a new National Health Insurance Scheme (NHS) (Chua, 2005;

Abdurrahim, 2009; Merican, 2009) The National Health Account was also created under the Minisry of Health (Jamila, 2010: Abdulrahim, 2009).

One good lesson that both Nigeria and Malaysia need to learned from the American and Canadian health insurance is the provision of tax subsidy for the purchasers in addition to the welfare contribution to the citizens, so as to energize purchase for private insurance and open up chances for more access to residents (Mark, 2001).

The two countries could also learn from the Israel system of healthcare finance from all source, such as, medical insurance fees, employer contribution, social security payments, (parallel tax), governmental allocations and national insurance institute. While funding for some specific health items will go to the National Health Accounts (NHA) as may be define by health insurance and safety programme selected by the country (Shmuel \& Mordechi, 1995). 
Up until presents moments, the dimension of healthcare and safety service provision is yet to be integrated systematically as one of the principal dimension in comparative analysis of healthcare and safety system research (Freeman, 2005; Wendt \& Thompson, 2004; Wendt \& Kohl, 2009).

There is also the fear that, the private sector once allowed operating, controlling them is somewhat a problem. This assertion was further elaborated by Nik and Daniel, (2009), that, the private sector is often associated with the use of illegitimate and unethical practices to maximize profit (Bennett et al., 1994; 2004 \& Rosenthal, 2000). Therefore, this study also focuses on evaluation of mechanism of control available to safeguard the customers/beneficiaries from excess premium charges by healthcare providers in the two countries.

Despite the flow of latest information and innovation in the healthcare services delivery system, there is yet poor record on the study that confirms the positive contribution of public-private partnership. The argument favoring private sector participation in the provision of healthcare services was centered on its 'so called' innovativeness, efficiency, and capabilities to learn from competitors.

Yet, literature shows that, even though governmental spending on the healthcare provision may reduce with the introduction of NHS reform, its administrative spending will skyrocket, and lesser control on over servicing, and the reluctance of private funds to encourage cost-containment method in private hospitals (Nik \& Daniel, 2009).

This study also focuses on the study of cost effectiveness of NHS reform as an alternative system of healthcare delivery in Nigeria and Malaysia.

\section{Conceptual frame and research hypothesis}

\subsection{Conceptual frame}

Alan and Joel, (2004) substantiate on the interests of the government to reform healthcare provision and delivery system. The intent is straight forward, according to them, to assure access to affordable health insurance by mitigating questionable selection and pricing practices by insurers and private healthcare providers. The postulation may sound a 'myth' rather than reality, but it is a rationalized perspective that actually navigated towards responding to particular phenomenon.

To further elaborated on Alan and Joel position, Mathew and Abraham, (2007) states that, it is fashionable just now to believe that health care coverage, health care costs, health care itself and its equity and fairness to the sick should rather be driven by consumer choice and responsibility only. Yet, the business of health care provision and delivery system for costs reduction, efficiency, accessibility, affordability and equitability should be a collective, rather than individual choice. The collectivism should include government, health organizations, insurance, individuals and all stakeholders. Though, we may sometimes wish to deny it, both general and specific issues of health and health care costs, efficiency, equity and access are often our joint responsibility (Mathew \& Abraham, 2007).

\subsection{Research hypothesis}

The following hypothesis will be considered in this study on the impacts of public/private mix in the health care and safety provision in Nigeria and Malaysia under reform.

2.2.1 There is significant relationship between the health care schemes in Nigeria andMalaysia under the reform; also we need to investigate if the scheme depends on Country.

2.2.2 There is significant relationship between the efficiency of public healthcare delivery and private healthcare delivery. Also we need to investigate if the scheme depends on the nature of the healthcare delivery.

2.2.3 There is significant relationship between public-private partnership and spread of innovation in both public and private healthcare delivery to the employees. Also we need to investigate if innovation for healthcare delivery depends on public-private partnership

3.

\subsection{Sample size determination, research design and data analysis}

The determination of sample size is a common task for many organizational researchers. Inappropriate, inadequate, or excessive sample sizes continue to influence the quality and accuracy of research. A formula for selecting the sample size for a research problem based on a level of significance and a set error rate was proposed by Cochran (1977). In order to obtain the most efficient, representative sample, for our research, we use the following Cochran's formula for sample size determination: 
Level of Significance:

$$
\alpha=0.05
$$

Test statistic:

$$
\chi^{2}=\sum_{i=1}^{r} \sum_{j=1}^{c} \frac{\left(O_{i j}-e_{i j}\right)^{2}}{e_{i j}}
$$

Decision Criterion:

$$
\begin{gathered}
\text { Reject } H_{0} \text { if } p<0.05 \text { otherwise accept } H_{0} \\
n=\left(\frac{Z_{\alpha / 2} \hat{\sigma}}{\delta}\right)^{2} \text { Where; } \\
n=\text { Sample size }
\end{gathered}
$$

$Z_{\alpha / 2}=$ The value of the standard normal ordinate at $\alpha \%$ level of significance

Hence, at the $5 \%$ level of significance, we can compute the value as;

$\delta=$ The chosen error rate; we can set $\delta=0.03$

$\hat{\sigma}=$ The estimated population standard deviation (for educational level) $=0.411$

$$
n=\left(\frac{Z_{\alpha / 2} \hat{\sigma}}{\delta}\right)^{2}=\left(\frac{1.96 \times 0.411}{0.03}\right)^{2}=721
$$

\subsection{Computation criterion}

Based on the above computation, this study needed 750 respondents to complete the survey using the questionnaire instrument. This size range was as suggested by Ferketich, (1991) and Dillman, (2000), in that the size of 200-300 should be considered for a survey. It was within the sample frame of plus or minus 5\% margin errors based on the formular and sample size table of Krejgie and Morgan (1970). Normally "p" is set at 0.01 or 0.05 for more homogeneous sample (Dill man, 2000).

\subsection{Population of the study}

The population of the study comprises of the medical practitioners, safety experts, healthcare and safety beneficiaries, and staff of both private and public clinics in both Nigeria and Malaysia. The six randomly selected institutions from which the respondents were selected includess Kaduna City University of Technology (Kaduna polytechnic), Ahmadu Bello University (ABU), American University (AU) Bayero University Kano (BUK), Shehu Idris College of Health Technology Makarfi, and Public/Private Clinics in Nigeria. In Malaysia, the selected institutions for the research includes ; Universiti Malaya, Universiti Putra Malaysia (UPM), Universiti Utara Malaysia (UUM), Universiti Sains Malaysia (USM),Cyberjaya University College of Medical Sciences (CUCMS) and some selected Public/private clinics in Malaysia. A sample of 750 based on Cochran (1977) formular was selected as adequate for this study. The 750 comprises of 500 for Nigeria and 250 for Malaysia. Sampling adequacy issue was well debated by schoolars such as (Any et al., 1998; Macmicky, 1993). A stratified random sampling was adopted for its administrative and precision in survey results compilation.

\subsection{Reliability test}

Cronbach's alpha is designed as a measure of internal consistency; that is, a test of whether all items within the instrument measure the same thing. It is simply a measure of reliability of the question items. Alpha is measured on the same scale as the Pearson's product-moment correlation coefficient and typically varies between 0 and 1 .

Although a negative value is possible, such a value indicates a scale in which same items measure the opposite of what other items measure. The closer the alpha is to 1.00 , the greater the internal consistency of items in the instrument being assessed. This study recorded a cronbach's alpha of 0.911 for the instrument used in Nigeria which implies that the Nigerian instrument is reliable. Similarly, the cronbach's alpha of 0.920 for the instrument used in Malaysia implies that the Malaysian instrument is also reliable. Both instruments have excellent reliability as far as internal consistency is concerned.

\subsection{Content validity}

Inorder to content validate the questionnaire, the draft of the questionnaire was sent to expert to content validate as suggested by Grent \& Davis (1998); Lyn (1986), that the content experts should be between 3-10 in number, 
this study relied on this and sent the instrument to 10 experts from both Nigeria and Malaysia. The experts who content valdate the instrument include medical personel, psychologists, safety experts, educationists, human resources experts as well as College/Faculty members of UUM and PhD. Students and College Members of Kaduna City University (kad-poly) Nigeria. Additional validation was conducted through thourough review by the researcher and his supervisor inorder to detect and correct the anomalies identified by experts and other content reviewers. These corrections range from wording and terminological misplacements.

\subsection{Analyses of variance}

To test the hypotheses and determine the relationship between the variables an anlyses of variance ANOVA was used. The hyposes were tested to inorder to get the difference between Nigeria and Malaysia as well as the difference before the reform and after the reform. One-way analysis of variance to accomplish this using the formular as cited below. The formular was imputed into the step-by-step ANOVA in SPSS and the result was process and analysed.

\subsection{Hypothesis}

$$
\begin{array}{l|l}
H_{0}: \mu_{1}=\mu_{2}=\ldots=\mu_{p} & \text { (There is no significant difference in the population means) } \\
H_{1}: \mu_{1} \neq \mu_{2} \neq \ldots \neq \mu_{p} & \text { (There is significant difference in the population means) }
\end{array}
$$

Level of Significance:

$$
\alpha=0.05
$$

Test statistic:

$$
F^{*}=\frac{M S(\text { Treatmant })}{M S E}
$$

Decision Criterion:

$$
\text { Reject } H_{0} \text { if } p<0.05 \text { otherwise accept } H_{0}
$$

\section{Computations:}

\section{Results discussion}

From the log-linear and chi-square test, since p-value is less than 0.05 in each case we can conclude that the recent development in the healthcare sector is dependent on the country. The nominal correlation coefficient of $\mathrm{r}-0.257$ (table 4) shows that there is a weak but significant relationship between the healthcare schemes for safety and health of employees in Nigeria and Malaysia. These results had shown that there is a historical relationship between Nigeria and Malaysian healthcare and safety scheme because of the colonial heritage. The two countries inherited their medical structures from British colony in the mid 1950's (Labiran et al., 2008; Nik \& Daniel, 2009). With this results we can now concludes that history had linked the two countries health system as confirm by the study above.

From the log-linear and chi-square test, since p-value of 0.008 and 0.005 respectively are less than 0.05 in each case we can conclude that the public controlled healthcare is dependent on the healthcare delivery for safety and health of employees. The nominal correlation coefficient of $r=0.164$ (table7) shows that there is weak relationship between the two attributes. There is weak but significant relationship between public controlled healthcare and healthcare delivery for safety and health of employees. Similar study was conducted by Raynald et al. (1993), on whether or not reform that targeted at combining both private and public healthcare and safety facilities to operate has a goal and or has succeeded in achieving such goals. The research summarised as follows, that the healthcare reform plan should have the likelihood of achieving maximum efficiency, but not to have the likelihood of plan of failure. The reform should have planned to succeed and work toward it. Any reform that is to the contrary may hardly achieve any efficient results. The researchers states that, the Quebec health care reform which achieve maximum efficiency, equity, access and has control over the excesses of power from both patients, providers and professionals. 
From the log-linear and chi-square test, since p-value of 0.006 and 0.005 respectively are less than 0.05 in each case we can conclude that the efficiency of public controlled health care depends on private healthcare delivery for employees safety and health. The nominal correlation coefficient of 0.168 (table 10) shows that there is weak relationship between the two attributes. There is weak but significant relationship between the efficiency of public healthcare delivery and private healthcare delivery for safety of employees. As suggested by Bloom, Craig, and Mitchell (2000) the private sector is neither so easy to characterize nor easy to neglect. Its strength is its innovativeness, efficiency and learning from competition.

This factor plus the fact that in many developing countries, the private sector accounts for a large proportion of services and resources in the health sector, it is argued that strategies to improve the health system and payments should take into account of the strengths of the private sector (World Bank, 2004).

From the log-linear and chi-square test, since p-value of 0.187 and 0.146 respectively are greater than 0.05 in each case we can conclude that the public-private partnership is independent of spread of innovation in both public and private. The nominal correlation coefficient of $\mathrm{r}-0.122$ (table 16) shows that there is weak relationship between the two attributes. There is weak and no significant relationship between spread of innovation in both public and private and public-private partnership in the area of health and safety of employees. Analyses conducted by the former US secretary of health on the state of the impact of reform on the American health system remain that reform from the control side most divulge some powers from the central authority to the states and the private sector. This single act will help in evolving a new trend in the development of competition, transfer of innovation, new models of providing care and expanding coverage to healthcare and safety beneficiaries. In this case there will be reduction in extra spending by both the government and individual citizens (Michael, 2011).

\subsection{Suggestion}

Based on our findings there is an established relationship between healthcare delivery systems under reform in the two countries, either due to the universality of the phenomena or existence of other factors such as geographic factors, political systems and as well as demographic similarities of their population and/or health care delivery mothods. This study therefore, suggested the coming up of a healthcare data from ciuntries and regional level which will serve as base line for evolution of worldwide comparative analysis of reform success or failure with certainty.

\section{References}

Abdurrahim, M. (2009). Future of Health Care Financing In Malaysia, Planning and Development Division Ministry of Health Malaysia.

Agha, S. A. M., Karim, A., \& Balal, S. Sossler. (2003). A Quasi-Experimental Study to Asses the Performance of a Reproductive Health Franchise in Nepal.

Alan, C. M. \& Joel, C. C. (2004). State Health Insurance Market Reform; towards inclusive and sustainable health insurance markets, London and New York: Routledge Taylor \& Francis Group.

Bennette, K. M., Georgina, H., \& Marion, M. H. (2004). Old and alone: barriers to healthy eating in older men living on their own: 43, 269-276. http://dx.doi.org/10.1016/j.appet.2004.06.002

Bloom, D. E., Craig, P., \& Mitchell, M. (2000). Public/Private Partnership in Health Care Services in India: The World Bank Report 1993, Washington DC.

Chua, S. L. (2004). Incoporating the $7^{\text {th }}$ Scientific Meeting of National Institutes of Health: Academy of Medicine Malaysia; Speech by Malaysian Minister of Health at the Opening Ceremony of $5^{\text {th }}$ Academy of Science Meeting Cochran, J. J. (2000). Career records for all modern position players eligible for the Major League Baseball Hall Fame. Journal of statistics education, 8, 1-5.

Collins, J. J. \& Alison, M. M. S. (1983). Legal Coersion and Retention in Drug Abuse Treatments; Journal of Hospital Community Psychiatric Association, 34, 1145-1149.

Ferketich, S. (1991). Aspects of Item Analysis: Research in Nursing and Health, 14, 165-168. http://dx.doi.org/10.1002/nur.4770140211

Goetsh, D. (2005). Occupational Safety and Health for Technologists, Engineers, and Managers (5th eds.). New Jersey, Columbus, Ohio: Upper Saddle River.

HERFON, H. R. (2006). Capacity Building/Study Tour of Brazil's Health Insurance System. Abuja-Nigeria: HERFON. 
Jamila Zainuddin. (2010). Institutionalizationof National Health Accounts in Malaysia. Head of MNHA unit Planning and Development Division MOH Malaysia.

Juttling, J., Drechsler, D., Sebastian, B., \& Indra, de S. (2005). Informal Institution: An Emerging Topic

Krejgie, R. D. W. \& Morgan. (1970). Determining the Sample Size for Research Activities Educational and Psychological Measurement, 30, 607-610.

Lyn, C. J., Mckernan Mckay, M., \& Atkin, M. (2003). School Social Work. Meeting the mental health needs of students through collaboration with teachers. National Association of Social Workers.

Lynn, M. R. (1986). Determination and Quantification of Content Validity, Nursing Research, 35, 282-285. http://dx.doi.org/10.1097/00006199-198611000-00017

Mark, S. (2001). Private insurance subsidies and public healthcare markets: Evidence from Canada. Journal of the Canadian Economics/Revenue Candienne d'Economique, 34(2), 921-942.

McAuley, G. A. (1993). Health Insurance Coverage, Bureau of Census: statistical Brief.

Merican, M. I. (2009). Applying best practices in Health Care Delivery: International Healthcare Comference and Exhibition, July 21-23. Kuala Lumpur Convention Cemtre Malaysia.

NHIS Decree 35. (1999). Law of the Federation of Nigeria (Constitution). Zaria-Nigeria: Gaskiya Corporation.

OSHA. (2005). Worker Safety Series: Construction; Pocket Guide. [Online] Available: http: www.osha.gov.

Propper, C., Simon, B., \& Green, K. (2004). Does Competition between Hospitals. Improves the Quality of Care? Hospital death rates and the NHS internal Market. Journal of Economics, 8, 1247-1272.

Ramesh, M. \& Wu, K. (2008). Realighning Public and Private Health Care in Southeastern Asia; Pacific Review, 21 (2), 171-187. http://dx.doi.org/10.1080/09512740801990238

Raynolds, P., Poul, A., Francois, C., Andre-Pierre, \& Jean lonis, D. (1993). The Reform of the Quebec Healthcare System: Potential for Innovation. Palm Grave Macmillan Journals, 14 (2), 198-219.

Rosenthel, T. C. (2000). Access to Healthcare for the Rural Elderly; Linking Evidence and Experience. Journal JAMA, 284(16), 2034-2036.

Shmuel, P. \& Mordechi, S. (1995). Redesigning a national healthcare system; the Israel experience: Describes major steps to develop and reform Israel's health services. International journal of health care quality Assurance, 8 (2), 9-17.

Wendt, C. \& Thompson, T. (2004). Social Austerity versus Structural Reform in European Health System A Four-Country Comparison of Health Reform. International Journal of Health Service, 34 (3), 415-433. http://dx.doi.org/10.2190/DJ9Q-F2GY-W18R-4C1J

WHO. (2001). Mental Health Report. A Report on Observation of Mental Health Systems in the United States, the United Kingdom and Elsewhere.

WHO. (2004). National Health Care Quality Report, Agency Health Care and Quality Advancing Excellence in Health Care. [Online] Available: http: www.ahrq.gov

WHO. (2009). World Health Statistics; Health Inequalities. World Health Report. 
The following table depicts the value of the sample standard deviation which is an estimator for the population standard deviation.

Table 1. Descriptive Statistics for sample size determination

\begin{tabular}{|l|l|l|l|l|l|}
\hline & $\mathrm{N}$ & Minimum & Maximum & Mean & Std. Deviation \\
\hline Highest Educational Achievement & 290 & 4 & 5 & 4.21 & 0.411 \\
\hline Valid N (listwise) & 290 & & & & \\
\hline
\end{tabular}

Table 2. Cross-Tabulation 1

On the recent development in health sector will ensures equity of healthcare services, thereby making safety and health practice possible in the working place by Country

\begin{tabular}{|c|c|c|c|c|c|}
\hline & & & Country & & \\
\hline & & & Nigeria & Malaysia & Total \\
\hline The recent development & Strongly Disagreed & Count & 15 & 13 & 28 \\
\hline & & Expected Count & 18.7 & 9.3 & 28.0 \\
\hline & Disagreed & Count & 32 & 25 & 57 \\
\hline & & Expected Count & 38.0 & 19.0 & 57.0 \\
\hline & Undecided & Count & 58 & 73 & 131 \\
\hline & & Expected Count & 87.3 & 43.7 & 131.0 \\
\hline & Agree & Count & 284 & 115 & 399 \\
\hline & & Expected Count & 266.0 & 133.0 & 399.0 \\
\hline & Strongly Agree & Count & 111 & 24 & 135 \\
\hline & & Expected Count & 90.0 & 45.0 & 135.0 \\
\hline Total & & Count & 500 & 250 & 750 \\
\hline & & Expected Count & 500.0 & 250.0 & 750.0 \\
\hline
\end{tabular}

Table 3. Log-linear Models and Chi-Square Tests 1

\begin{tabular}{|l|l|l|l|}
\hline & Value & Df & Asymp. Sig. (2-sided) \\
\hline Pearson Chi-Square & 52.914 & 4 & 0.000 \\
\hline Likelihood Ratio & 52.456 & 4 & 0.000 \\
\hline Linear-by-Linear Association & 34.733 & 1 & 0.000 \\
\hline N of Valid Cases & 750 & & \\
\hline
\end{tabular}

Table 4. Nominal Correlation Measures 1

\begin{tabular}{|l|l|l|l|}
\hline \multicolumn{2}{|l|}{} & Value & Approx. Sig. \\
\hline Nominal by Nominal & Contingency Coefficient & 0.257 & 0.000 \\
\hline N of Valid Cases & 750 & \\
\hline
\end{tabular}


Table 5. Cross-Tabulation 2

The tool of controlling healthcare providers for effective healthcare delivery for safety of the employee is through HMO's by Clinic Attended

\begin{tabular}{|c|c|c|c|c|c|c|}
\hline & \multicolumn{3}{|c|}{ Clinic Attended } & \multirow[b]{2}{*}{ Total } \\
\hline & & & $\begin{array}{l}\text { Public/go } \\
\text { vernment } \\
\text { al hospital }\end{array}$ & $\begin{array}{l}\text { Private } \\
\text { hospitals }\end{array}$ & $\begin{array}{l}\text { Private } \\
\text { \& Public } \\
\text { Hospitals }\end{array}$ & \\
\hline \multirow{10}{*}{$\begin{array}{l}\text { That the tool of } \\
\text { control of } \\
\text { healthcare for } \\
\text { safety of the } \\
\text { employee }\end{array}$} & \multirow{2}{*}{$\begin{array}{l}\text { Strongly } \\
\text { Disagreed }\end{array}$} & Count & 1 & 3 & 5 & 9 \\
\hline & & Expected Count & 2.5 & 2.7 & 3.8 & 9.0 \\
\hline & \multirow[t]{2}{*}{ Disagreed } & Count & 23 & 13 & 37 & 73 \\
\hline & & Expected Count & 20.1 & 22.3 & 30.7 & 73.0 \\
\hline & \multirow[t]{2}{*}{ Undecided } & Count & 82 & 111 & 145 & 338 \\
\hline & & Expected Count & 92.8 & 103.2 & 142.0 & 338.0 \\
\hline & \multirow[t]{2}{*}{ Agree } & Count & 94 & 89 & 102 & 285 \\
\hline & & Expected Count & 78.3 & 87.0 & 119.7 & 285.0 \\
\hline & \multirow{2}{*}{ Strongly Agree } & Count & 6 & 13 & 26 & 45 \\
\hline & & Expected Count & 12.4 & 13.7 & 18.9 & 45.0 \\
\hline \multirow{2}{*}{\multicolumn{2}{|c|}{ Total }} & Count & 206 & 229 & 315 & 750 \\
\hline & & Expected Count & 206.0 & 229.0 & 315.0 & 750.0 \\
\hline
\end{tabular}

Table 6. Log-linear Models and Chi-Square Tests 2

\begin{tabular}{|l|l|l|l|}
\hline & Value & Df & Asymp. Sig. (2-sided) \\
\hline Pearson Chi-Square & 20.628 & 8 & 0.008 \\
\hline Likelihood Ratio & 21.913 & 8 & 0.005 \\
\hline Linear-by-Linear Association & 0.742 & 1 & 0.389 \\
\hline N of Valid Cases & 750 & & \\
\hline
\end{tabular}

Table 7. Nominal Correlation Measures 2

\begin{tabular}{|l|l|l|l|}
\hline \multicolumn{2}{|l|}{} & Value & Approx. Sig. \\
\hline Nominal by Nominal & Contingency Coefficient & 0.164 & 0.008 \\
\hline N of Valid Cases & 750 & \\
\hline
\end{tabular}


Table 8. Cross-Tabulation 3

The efficiency provided in the recent development in the health sector will ensures equity, safety and healthcare services to employees in the working place by Clinic Attended

\begin{tabular}{|c|c|c|c|c|c|c|}
\hline & \multicolumn{3}{|l|}{ Clinic Attended } & \multirow[b]{2}{*}{ Total } \\
\hline & & & $\begin{array}{l}\text { Public/govern } \\
\text { mental } \\
\text { hospital }\end{array}$ & $\begin{array}{l}\text { Private } \\
\text { hospitals }\end{array}$ & $\begin{array}{l}\text { Private \& } \\
\text { Public } \\
\text { Hospitals }\end{array}$ & \\
\hline \multirow{4}{*}{\begin{tabular}{l|l} 
& \\
The efficiency & I \\
provided in & I \\
\cline { 3 - 3 } the recent & I \\
health sector &
\end{tabular}} & \multirow{2}{*}{$\begin{array}{l}\text { Strongly } \\
\text { Disagreed }\end{array}$} & Count & 5 & 8 & 8 & 21 \\
\hline & & Expected Count & 5.8 & 6.4 & 8.8 & 21.0 \\
\hline & \multirow[t]{2}{*}{ Disagreed } & Count & 7 & 13 & 17 & 37 \\
\hline & & Expected Count & 10.2 & 11.3 & 15.5 & 37.0 \\
\hline \multirow{6}{*}{$\begin{array}{l}\text { will ensures } \\
\text { equity, safety } \\
\text { and } \\
\text { healthcare } \\
\text { services to } \\
\text { employees in } \\
\text { the working } \\
\text { place. }\end{array}$} & \multirow[t]{2}{*}{ Undecided } & Count & 21 & 17 & 58 & 96 \\
\hline & & Expected Count & 26.4 & 29.3 & 40.3 & 96.0 \\
\hline & \multirow[t]{2}{*}{ Agree } & Count & 126 & 140 & 153 & 419 \\
\hline & & Expected Count & 115.1 & 127.9 & 176.0 & 419.0 \\
\hline & \multirow{2}{*}{ Strongly Agree } & Count & 47 & 51 & 79 & 177 \\
\hline & & Expected Count & 48.6 & 54.0 & 74.3 & 177.0 \\
\hline \multirow{2}{*}{\multicolumn{2}{|c|}{ Total }} & Count & 206 & 229 & 315 & 750 \\
\hline & & Expected Count & 206.0 & 229.0 & 315.0 & 750.0 \\
\hline
\end{tabular}

Table 9. Log-linear Models and Chi-Square Tests 3

\begin{tabular}{|l|l|l|l|}
\hline & Value & Df & Asymp. Sig. (2-sided) \\
\hline Pearson Chi-Square & 21.658 & 8 & 0.006 \\
\hline Likelihood Ratio & 21.891 & 8 & 0.005 \\
\hline Linear-by-Linear Association & 1.637 & 1 & 0.201 \\
\hline N of Valid Cases & 750 & & \\
\hline
\end{tabular}

Table 10. Nominal Correlation Measures 3

\begin{tabular}{|l|l|l|l|}
\hline \multicolumn{2}{|l|}{} & Value & Approx. Sig. \\
\hline Nominal by Nominal & Contingency Coefficient & 0.168 & 0.006 \\
\hline N of Valid Cases & 750 & \\
\hline
\end{tabular}


Table 11. Cross-Tabulation 5

Access and equity to health care services by government control mechanism

\begin{tabular}{|c|c|c|c|c|c|c|c|c|}
\hline & \multicolumn{5}{|c|}{ Control mechanism instituted by the government. } & \multirow{3}{*}{$\begin{array}{l}\text { Total } \\
19\end{array}$} \\
\hline & & & $\begin{array}{l}\text { Strongly } \\
\text { Disagreed }\end{array}$ & $\begin{array}{l}\text { Disagree } \\
\text { d }\end{array}$ & $\begin{array}{l}\text { Undeci } \\
\text { ded }\end{array}$ & $\begin{array}{l}\text { Agre } \\
\text { e }\end{array}$ & $\begin{array}{l}\text { Strongly } \\
\text { Agree }\end{array}$ & \\
\hline \multirow{10}{*}{$\begin{array}{l}\text { Access } \\
\text { and } \\
\text { equity to } \\
\text { healthca } \\
\text { re } \\
\text { services }\end{array}$} & \multirow{2}{*}{$\begin{array}{l}\text { Strongly } \\
\text { Disagreed }\end{array}$} & Count & 1 & 5 & 6 & 7 & 0 & \\
\hline & & Expected Count & 1.6 & 4.9 & 6.3 & 5.3 & 0.9 & 19.0 \\
\hline & \multirow{2}{*}{ Disagreed } & Count & 2 & 19 & 9 & 5 & 1 & 36 \\
\hline & & Expected Count & 3.1 & 9.3 & 12.0 & 10.0 & 1.7 & 36.0 \\
\hline & \multirow{2}{*}{ Undecided } & Count & 3 & 14 & 46 & 29 & 3 & 95 \\
\hline & & Expected Count & 8.1 & 24.4 & 31.5 & 26.3 & 4.6 & 95.0 \\
\hline & \multirow{2}{*}{ Agree } & Count & 42 & 125 & 149 & 132 & 18 & 466 \\
\hline & & Expected Count & 39.8 & 119.9 & 154.7 & 129.2 & 22.4 & 466.0 \\
\hline & \multirow{2}{*}{$\begin{array}{l}\text { Strongly } \\
\text { Agree }\end{array}$} & Count & 16 & 30 & 39 & 35 & 14 & 134 \\
\hline & & Expected Count & 11.4 & 34.5 & 44.5 & 37.2 & 6.4 & 134.0 \\
\hline \multirow{2}{*}{\multicolumn{2}{|c|}{ Total }} & Count & 64 & 193 & 249 & 208 & 36 & 750 \\
\hline & & Expected Count & 64.0 & 193.0 & 249.0 & 208.0 & 36.0 & 750.0 \\
\hline
\end{tabular}

Table 12. Log-linear Models and Chi-Square Tests 5

\begin{tabular}{|l|l|l|l|}
\hline & Value & Df & Asymp. Sig. (2-sided) \\
\hline Pearson Chi-Square & 44.554 & 16 & 0.000 \\
\hline Likelihood Ratio & 42.524 & 16 & 0.000 \\
\hline Linear-by-Linear Association & 0.301 & 1 & 0.583 \\
\hline N of Valid Cases & 750 & & \\
\hline
\end{tabular}

Table 13. Nominal Correlation Measures 5

\begin{tabular}{|l|l|l|l|}
\hline \multicolumn{2}{|l|}{} & Value & Approx. Sig. \\
\hline Nominal by Nominal & Contingency Coefficient & 0.237 & 0.000 \\
\hline N of Valid Cases & 750 & \\
\hline
\end{tabular}


Table 14. Cross-Tabulation 6

Partnership of private and government hospitals in the same environment by Type of Clinic

\begin{tabular}{|c|c|c|c|c|c|c|}
\hline & & & Types of Clinic & & & \\
\hline & & & $\begin{array}{l}\text { Public/governmental } \\
\text { hospital }\end{array}$ & $\begin{array}{l}\text { Private } \\
\text { hospitals }\end{array}$ & $\begin{array}{l}\text { Private } \\
\text { \& Public } \\
\text { Hospitals }\end{array}$ & Total \\
\hline As an employee & Strongly & Count & 9 & 3 & 15 & 27 \\
\hline $\begin{array}{ll}\text { would } & \text { you } \\
\text { support } & \end{array}$ & Disagreed & $\begin{array}{l}\text { Expected } \\
\text { Count }\end{array}$ & 7.4 & 8.2 & 11.3 & 27.0 \\
\hline reform in & Dicaoreed & Count & 12 & 20 & 17 & 49 \\
\hline $\begin{array}{l}\text { health care } \\
\text { sector that is }\end{array}$ & & $\begin{array}{l}\text { Expected } \\
\text { Count }\end{array}$ & 13.5 & 15.0 & 20.6 & 49.0 \\
\hline private and & Undecided & Count & 22 & 28 & 33 & 83 \\
\hline $\begin{array}{l}\text { government } \\
\text { hospitals in the }\end{array}$ & & $\begin{array}{l}\text { Expected } \\
\text { Count }\end{array}$ & 22.8 & 25.3 & 34.9 & 83.0 \\
\hline same & Aoreo & Count & 118 & 119 & 159 & 396 \\
\hline & & $\begin{array}{l}\text { Expected } \\
\text { Count }\end{array}$ & 108.8 & 120.9 & 166.3 & 396.0 \\
\hline & & Count & 45 & 59 & 91 & 195 \\
\hline & $\begin{array}{l}\text { Strongly } \\
\text { Agree }\end{array}$ & $\begin{array}{l}\text { Expected } \\
\text { Count }\end{array}$ & 53.6 & 59.5 & 81.9 & 195.0 \\
\hline Total & & Count & 206 & 229 & 315 & 750 \\
\hline & & $\begin{array}{l}\text { Expected } \\
\text { Count }\end{array}$ & 206.0 & 229.0 & 315.0 & 750.0 \\
\hline
\end{tabular}

Table 15. Log-linear Models and Chi-Square Tests 6

\begin{tabular}{|l|l|l|l|}
\hline & Value & Df & Asymp. Sig. (2-sided) \\
\hline Pearson Chi-Square & 11.259 & 8 & 0.187 \\
\hline Likelihood Ratio & 12.117 & 8 & 0.146 \\
\hline Linear-by-Linear Association & 0.584 & 1 & 0.445 \\
\hline N of Valid Cases & 750 & & \\
\hline
\end{tabular}

Table 16. Nominal Correlation Measures 6

\begin{tabular}{|l|l|l|l|}
\hline \multicolumn{2}{|l|}{} & Value & Approx. Sig. \\
\hline Nominal by Nominal & Contingency Coefficient & 0.122 & 0.187 \\
\hline N of Valid Cases & 750 & \\
\hline
\end{tabular}

